\title{
INFLUENCE OF TRANSIENT CHANGE OF WATER TEMPERATURE ON PILOT-SCALE ANAEROBIC-ANOXIC-OXIC PROCESS UNDER PLATEAU ENVIRONMENTAL FACTORS
}

\author{
ZONG, Y. ${ }^{1,2}-\mathrm{LI}, \mathrm{Y}^{2}-\mathrm{HAO}, \mathrm{K} .{ }^{2}-\mathrm{LU}, \mathrm{G} .{ }^{1,2^{*}}-\mathrm{HUANG}, \mathrm{D} .{ }^{2}$ \\ ${ }^{1}$ Res. Institute of Tibet Plateau Ecology, Tibet Agriculture \& Animal Husbandry University, \\ Linzhi 860000, China \\ ${ }^{2}$ Water Conservancy Project \& Civil Engineering College, Tibet Agriculture \& Animal \\ Husbandry University, Linzhi 860000, China \\ *Corresponding author \\ e-mail:ghlu@hhu.edu.cn
}

(Received $1^{\text {st }}$ May 2019; accepted $11^{\text {th }}$ Jul 2019)

\begin{abstract}
The objective of this study was to explore the effect of transient changes of Pilot-Scale Anaerobic-Anoxic-Oxic Process (A2O). The effects of transient changes in Tibet, China of water temperature on water quality indicators such as chemical oxygen demand (COD), the total phosphorous (TP), total nitrogen (TN) and ammoniacal nitrogen $\left(\mathrm{NH}_{4}{ }^{+}-\mathrm{N}\right)$, as well as microorganism and mixed liquor suspended solids were analyzed. The A2O system had a hydraulic retention time of $21 \mathrm{~h}$, a mixture of the reflux ratio of the mixed liquor of $200 \%$, a reflux ratio of the sludge of $100 \%$, a temperature fluctuation range of $8-25^{\circ} \mathrm{C}$, and a water sampling interval of $3 \mathrm{~h}$. The results showed that the optimal removal rates of different water quality indicators were different. The removal of COD, TN and $\mathrm{NH}_{4}{ }^{+}-\mathrm{N}$ mainly occurred in anaerobic tank and TP mainly in anaerobic tank and oxic tank. There was no obvious relationship between microorganism density and indicator organisms in anoxic tank, oxic tank and anaerobic tank. The concentrations of COD, TP, TN and $\mathrm{NH}_{4}{ }^{+}-\mathrm{N}$ in the effluents did not meet the first grade A standards, and the mixed liquid suspended solids did not show a significant growth trend with increasing temperature.
\end{abstract}

Keywords: nitrogen and phosphorus removal, dissolved oxygen, microorganism, A2O, Tibet

\section{Introduction}

Currently, the Anaerobic-Anoxic-Oxic (A2O) process, improved from the traditional activated-sludge process, has become the most popular sewage treatment method in Tibet, China (Chen et al., 2018). The sewage temperature in Tibet has obvious inter-annual and diurnal changes, the daily temperature difference can reach about $10^{\circ} \mathrm{C}$, and the interannual temperature difference can reach about $15^{\circ} \mathrm{C}$, which is mainly caused by drastic change of environmental temperature and centralized of water consumption time. Frequent change of water temperature could influence microbial growth and community structure, and adsorption performance and sedimentation performance of activated sludge, which ultimately leads to large fluctuations in wastewater treatment efficiency.

It is widely agreed that the effect of $\mathrm{A} 2 \mathrm{O}$ is influenced by the unique environment factors of the plateau, namely, water temperature and atmospheric pressure. At present, according to the on-site measurement, the lowest temperature of sewage in Linzhi City is $1{ }^{\circ} \mathrm{C}$, the highest is $14^{\circ} \mathrm{C}$ (Zong et al., 2018). According to the comprehensive analysis of the survey, the reason for the sewage temperature of $-1^{\circ} \mathrm{C}$ in Linzhi City is mainly due to the following two reasons: firstly, the sewage pipeline in Linzhi City is too long, and the sewage flow is too small, resulting to a large heat loss in the sewage flow; secondly, the 
groundwater level is too high, and some groundwater seeps into the sewage pipeline, causing its average temperature to be too low (Zong, 2017).

Our previous study has shown that the traditional activated-sludge process cannot satisfactorily remove nitrogen and phosphorus from domestic sewage in Tibet (Zong, 2017). Temperature is a main influencing factor of sewage treatment efficiency (Ai et al., 2018). In the process of the phosphorus removal of sludge denitrification, the release and absorption rates of phosphorus are changed under excessively high or low temperatures, and the proportion of denitrifying phosphorus accumulating organisms in the activated sludge is greatly affected by temperature variation (Zhang et al., 2016). In addition, the nitrification capacity of the sewage treatment system is obviously weakened when the water temperature falls below $15^{\circ} \mathrm{C}$, and even lost totally when the temperature drops below $4{ }^{\circ} \mathrm{C}$ (He et al., 2010; Li et al., 2013). Thus, the nitrogen removal is severely inhibited under a low temperature (Li et al., 2014).

As for the $\mathrm{A} 2 \mathrm{O}$ process, the nitrification/denitrification is weakened at a low temperature and a high sludge load. In this case, nitrite nitrogen will accumulate in the system, and denitrifying phosphorus removal will happen in the anoxic tank. The phosphorus removal efficiency of the system could decline due to the sludge bulking induced by nonfilamentous bacteria ( $\mathrm{Li}$ et al., 2014), and the lack of small molecular carbons required for phosphorus release by phosphorus-concentrating bacteria (as the hydrolysis of macromolecular organic matter is suppressed under a low temperature) (Shen et al., 2017).

The atmospheric pressure has a direct bearing on the oxygen partial pressure, and the oxygen partial pressure controls the dissolved oxygen (DO) in water. When partial oxygen pressures was below $40 \mathrm{kPa}$, the removal efficiencies of chemical oxygen demand (COD), and ammoniacal nitrogen $\left(\mathrm{NH}_{4}{ }^{+}-\mathrm{N}\right)$ increased with the increase of $\mathrm{DO}$, meanwhile, nitrification was the main control process in simultaneous nitrification and denitrification (SND). However, partial oxygen pressures above $40 \mathrm{kPa}$ did not affect their removal efficiencies, and denitrification became the main control process in SND (Xing et al., 2013). The nitrification can be enhanced by extending the aeration time, while the denitrification can be stimulated by prolonged exposure to anaerobic conditions (Yoo and Lee, 2015). Under low aeration, the nitrogen and phosphorus removal were greatly hindered in the A2O system (Li et al., 2013). The DO could affect the conversion of polyhydroxy alkyl ester and glycogen (Chen et al., 2014), as well as the activity of desulfurase and polyphosphatase, and affect phosphorus removal subsequently. The total number and activity of ammonia oxidizing bacteria are respectively determined by the hydraulic retention time (HRT) of solids and the DO concentration (Limpiyakorn et al., 2005).

Transient and non-steady state of domestic sewage is relatively common, and the temperature of sewage varies significantly during a day in Tibet. The present study used A2O system as a typical sewage treatment process to investigate the removal rates of nitrogen and phosphorus in daily responding to water temperature change, analyze the characteristics of the microbes in anaerobic tank, anoxic tank and oxic tank, and explore the mechanisms of nitrogen and phosphorus removal and microbial transient response under plateau environmental factors.

\section{Materials and methods}

\section{Description of the anaerobic-anoxic-oxic process system and wastewater}

A pilot-scale $\mathrm{A} 2 \mathrm{O}$ sewage treatment device was designed and fabricated with plexiglass in Tibet, China. With an effective volume of $210 \mathrm{~L}$, the device consists of 8 segments: the 
first 2 are anaerobic tanks with an effective volume of $35 \mathrm{~L}$, the middle 2 are anoxic tanks with an effective volume of $58 \mathrm{~L}$, and the last 4 are oxic tanks with an effective volume of $117 \mathrm{~L}$. Besides, the effective volume of the sedimentation tank is $210 \mathrm{~L}$. In both anaerobic and anoxic sections, each tank has a $50 \mathrm{rpm}$ stirring device at the bottom; in each oxic tank, there is an aerator for oxygen supply. Inflow, return sludge and nitrifying liquid are controlled by a peristaltic pump. To maintain a constant temperature, the water temperature was regulated by a constant temperature circulator. In each tank, a sampling hole was opened on the tank wall. Before the experiment, the activated sludge was cured for $32 \mathrm{~d}$. The temperature, MLSS, and volume percent of MLSS after settling for 30 min (SV30) were set to $22.5^{\circ} \mathrm{C}, 4,787 \mathrm{mg} / \mathrm{L}$ and $35 \%$, respectively.

The urban domestic sewage in Linzhi was directly adopted for our experiments. The main water quality indices of the sewage are given in Table 1.

Table 1. Quality indicators of sewage

\begin{tabular}{c|c|c|c|c|c|c}
\hline $\begin{array}{c}\text { Potential of } \\
\text { hydrogen }\end{array}$ & $\begin{array}{c}\text { Dissolved } \\
\text { oxygen }(\mathbf{m g} / \mathbf{L})\end{array}$ & $\begin{array}{c}\text { Temperature } \\
\left({ }^{\circ} \mathbf{C}\right)\end{array}$ & $\begin{array}{c}\text { Chemical oxygen } \\
\text { demand }(\mathbf{m g} / \mathbf{L})\end{array}$ & $\begin{array}{c}\text { Total nitrogen } \\
(\mathbf{m g} / \mathbf{L})\end{array}$ & $\begin{array}{c}\text { Total phosphorous } \\
(\mathbf{m g} / \mathbf{L})\end{array}$ & $\begin{array}{c}\text { Ammoniacal } \\
\text { nitrogen }(\mathbf{m g} / \mathbf{L})\end{array}$ \\
\hline $6.20 \sim 8.70$ & $1.87 \sim 4.68$ & $8.05 \sim 23.10$ & $217.17 \sim 526.36$ & $23.12 \sim 112.51$ & $2.59 \sim 7.28$ & $12.09 \sim 45.15$ \\
\hline
\end{tabular}

\section{Operation of the anaerobic-anoxic-oxic process}

The operation of the $\mathrm{A} 2 \mathrm{O}$ device was studied under transient change of water temperature, in order to disclose the law of removal rates under different water temperatures. The control plans for the three parameters are specified below. On water temperature control, the inlet water flow was designed as $10.0 \pm 0.1 \mathrm{~L} / \mathrm{s}, \mathrm{HRT}$ as $21.0 \pm 0.2 \mathrm{~h}$ (the HRT ratio between anaerobic tank, anoxic tank and oxic tank $=35: 58: 117$ ), DO as 3.0 4.0 mg/L, the reflux ratio of the mixed liquor $\mathrm{R}_{\mathrm{i}}=200 \%$, and the reflux ratio of the sludge $\mathrm{R}=100 \%$. Both the mixed liquor and the sludge were continuously refluxed. Temperature fluctuation range is set to $8 \sim 25^{\circ} \mathrm{C}$. The temperature was controlled with an error of or less than $0.1^{\circ} \mathrm{C}$. The experiment was replicated three times. Water quality sampling interval was $3 \mathrm{~h}$ (Fig. 1).

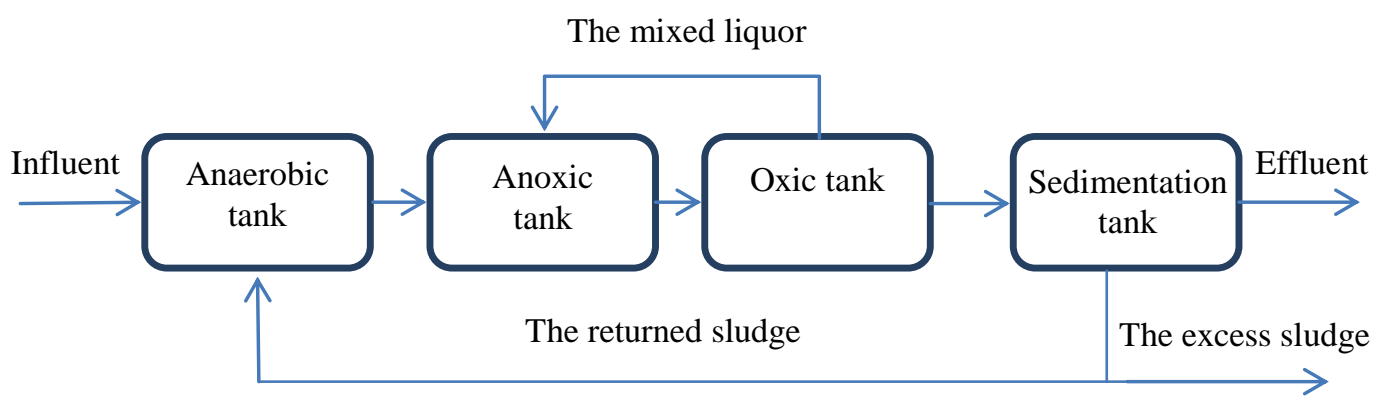

Figure 1. Schematic of anaerobic-anoxic-oxic process

\section{Analytical methods}

The measurement methods of the test indicators are selected according to the existing standards (State Environmental Protection Administration of China, 2002). 


\section{Statistical analysis}

All data were initially verified for normality using the Shapiro-Wilk method. The differences between different treatments were evaluated by one-way analysis of variance in SPSS, followed by Tukey's test. All differences were considered significant at $p<0.05$. All these statistical analyses were performed using the SPSS statistical package (ver. 22.0, SPSS Company, Chicago, IL, USA).

\section{Results}

\section{Removal rate at temperature transients}

Figures 2-5 provide the removal rates of $\mathrm{COD}, \mathrm{TP}, \mathrm{TN}$ and $\mathrm{NH}_{4}{ }^{+}-\mathrm{N}$ in anaerobic, anoxic and Oxic tanks at different temperatures.

As shown in Figure 2, the COD removal effect in the anaerobic tank maintains a good removal efficiency under the temperature from $8{ }^{\circ} \mathrm{C}$ to $25^{\circ} \mathrm{C}$. The removal efficiency of individual temperatures is low, and the average removal rate is $67.18 \%$, which is lower than $75.69 \%$ (Huang et al., 2017); COD is mainly removed in the anaerobic tank with a maximum removal rate of $89.09 \%$ and a minimum removal rate of $34.11 \%$ corresponding to the temperature of $18.2{ }^{\circ} \mathrm{C}$ and $22.3{ }^{\circ} \mathrm{C}$, respectively. The COD removal effect in the anoxic tank is generally acceptable, and the COD removal rate in the anoxic tank is only increased by $4.44 \%$, which is lower than $12.72 \%$ (Huang et al., 2017), which increases the maximum value by $15.91 \%$ and the minimum value of $-8.13 \%$ corresponding temperature are $22.3{ }^{\circ} \mathrm{C}$ and $15.1{ }^{\circ} \mathrm{C}$, respectively; the maximum removal rate of $87.48 \%$ and the minimum value of $50.02 \%$ corresponding temperatures are $18.2{ }^{\circ} \mathrm{C}$ and $22.3{ }^{\circ} \mathrm{C}$. The COD in the oxic tank can be removed as a whole due to the removal of the anaerobic tank and anoxic tank, but the average value of the relative anoxic removal rate is $10.07 \%$, which is larger than 5.98\% (Huang et al., 2017), the removal rate increases by a maximum of $27.69 \%$ and the minimum value of $-0.90 \%$, the corresponding temperatures are $8.98{ }^{\circ} \mathrm{C}$ and $18.2{ }^{\circ} \mathrm{C}$; the average COD removal rate is $81.69 \%$, and the maximum value of $91.15 \%$ and the minimum value of $70.06 \%$ corresponding temperature are $8.45^{\circ} \mathrm{C}$ and $17.50{ }^{\circ} \mathrm{C}$. The above trend is also consistent with the low temperature and room temperature COD treatment effects, but the effect is poor ( $\mathrm{Li}$ et al., 2012); according to the COD removal rate effect, the test temperature is $18.2{ }^{\circ} \mathrm{C}$, the removal rate can reach $92.19 \%$, the measured COD effluent can reach the first grade A standards (GB18918-2002), but other temperatures are difficult to reach this standard.

As shown in Figure 3, the TP removal effect in the anaerobic tank changes obviously between $3.54 \%$ and $83.41 \%$ at the temperature of $8 \sim 25{ }^{\circ} \mathrm{C}$. The removal efficiency of individual temperatures is low, and the average removal rate is $30.15 \%$, which is lower than 69\% (Bao et al., 2012). The highest TP removal rate of $63.58 \%$ and the lowest value of $5.56 \%$ corresponding temperatures are $12.00{ }^{\circ} \mathrm{C}$ and $22.40{ }^{\circ} \mathrm{C}$, respectively. The anoxic tank contributes very little to the TP removal rate which is only increased by only $2.50 \%$, which was lower than $56.00 \%$ (Zhou et al., 2013), which increased the maximum value by $20.19 \%$ and the minimum value by $-13.86 \%$ corresponding to temperatures of $14.70{ }^{\circ} \mathrm{C}$ and $8.05^{\circ} \mathrm{C}$, respectively; the maximum removal rate of $71.95 \%$ and the minimum value of $6.06 \%$ corresponding temperatures are $12.00{ }^{\circ} \mathrm{C}$ and $22.4^{\circ} \mathrm{C}$. The TP in the oxic tank is not obvious due to the poor removal rate of the anaerobic tank and anoxic tank, but the average value of the relative anoxic removal 
rate is $11.90 \%$. Considering the dilution of the anaerobic section, the effect of removing TP is more significant, but the overall TP removal rate is still low (Zhou et al., 2013), the removal rate increases by $46.93 \%$ and the minimum value by $-3.50 \%$, and the corresponding temperatures are $8.49{ }^{\circ} \mathrm{C}$ and $22.3{ }^{\circ} \mathrm{C}$, respectively; The average removal rate was $44.55 \%$, and the maximum values of $83.41 \%$ and the minimum value of $3.54 \%$ corresponding to the temperature of $12.00{ }^{\circ} \mathrm{C}$ and $22.40{ }^{\circ} \mathrm{C}$, respectively. When the test temperature is $12.00{ }^{\circ} \mathrm{C}$, the removal rate of $\mathrm{TP}$ can reach $83.41 \%$, and the sedimentation tank effluent regarding the TP can reach the grade $1 \mathrm{~B}$ standard (GB18918-2002), but TP removal rate can not reach this standard at the other temperatures. Overall, the removal rate of TP has two critical points of $9.54{ }^{\circ} \mathrm{C}$ and $14.70{ }^{\circ} \mathrm{C}$.

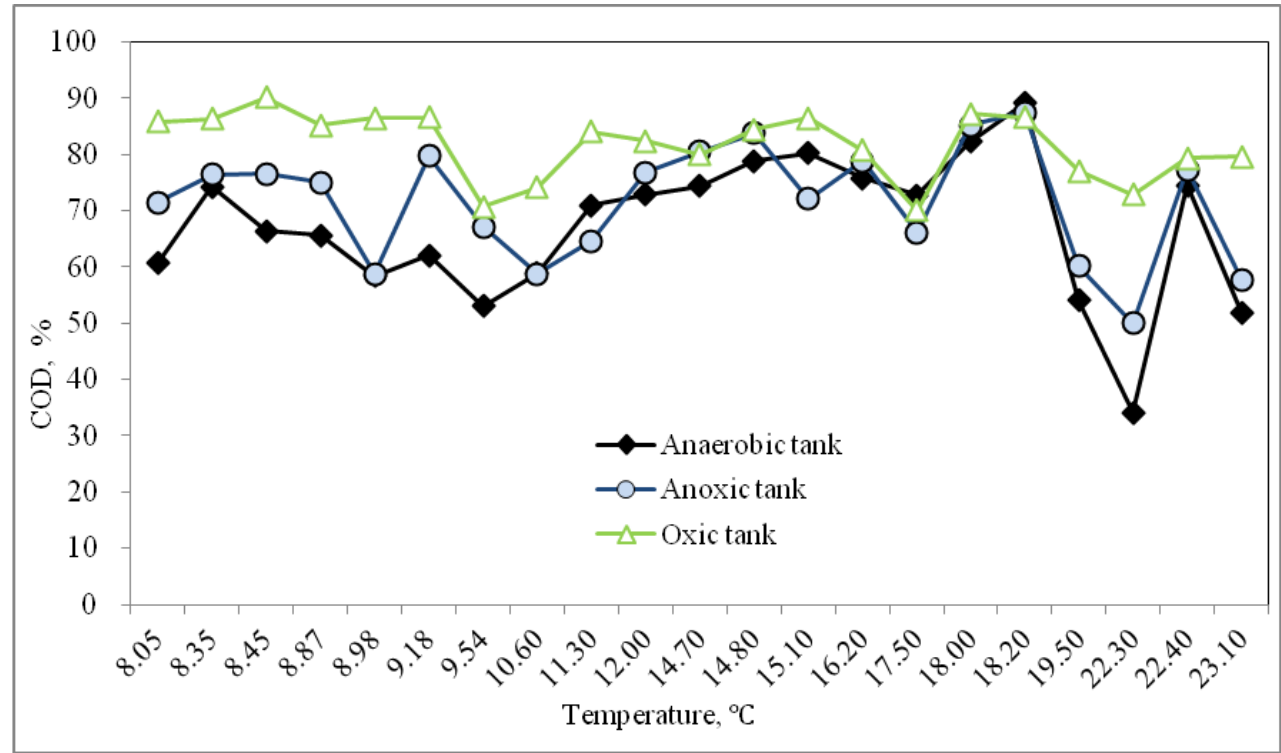

Figure 2. Removal rate of chemical oxygen demand at different temperatures

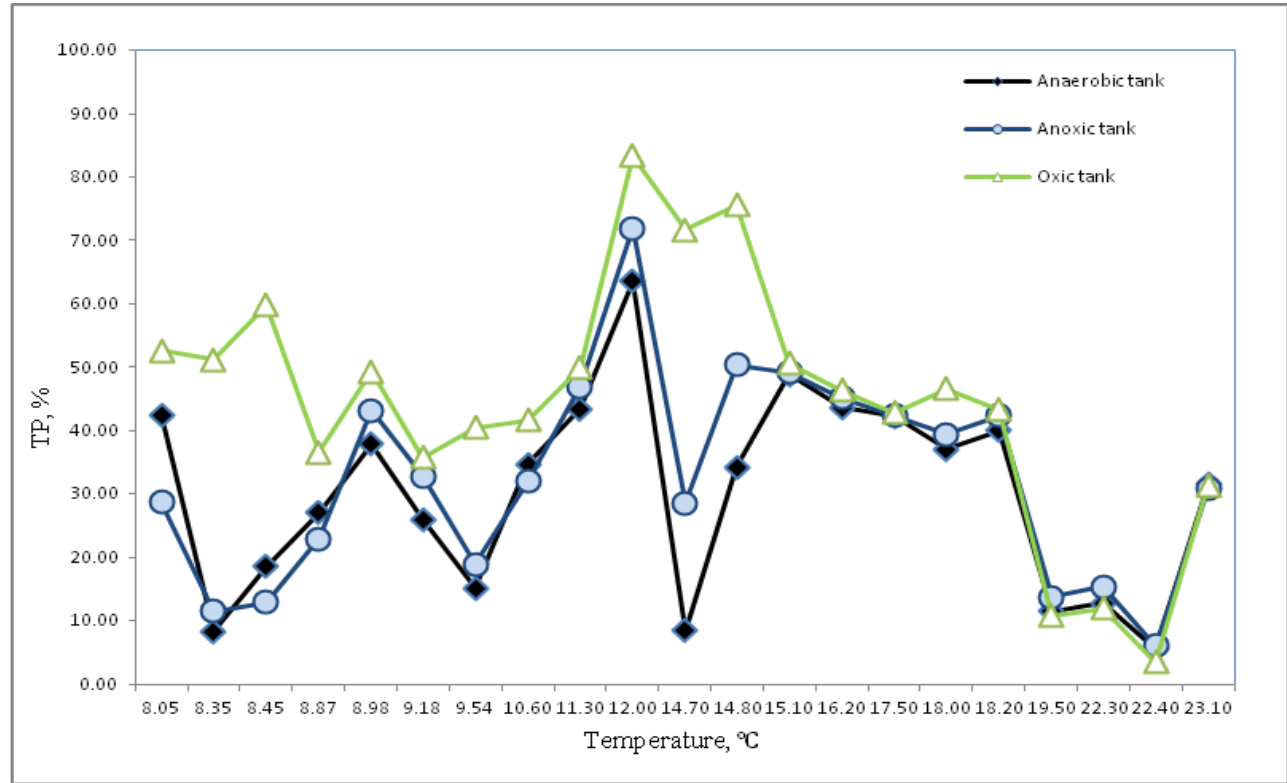

Figure 3. Removal rates of total phosphorous at different temperatures 
As shown in Figure 4, the TN removal rates in the anaerobic tank changes obviously between $1.34 \%$ and $95.37 \%$ when the temperature changed from $8{ }^{\circ} \mathrm{C}$ to $25^{\circ} \mathrm{C}$. The removal rate of TN is higher than other studies (Zhou et al., 2013). The average removal rate is $51.56 \%$, which is higher than the result obtained by Zhou et al. (2013). The anoxic tank contributes very little to the TN removal rate which is only increased by $5.53 \%$. The values corresponding to the value of $93.20 \%$ and the minimum of $20.23 \%$ corresponding to the temperatures were $9.18{ }^{\circ} \mathrm{C}$ and $8.35^{\circ} \mathrm{C}$. The $\mathrm{TN}$ in the oxic tank is not obvious due to the poor removal rate of the anaerobic tank and anoxic tank, but the average value of the relative anoxic removal rate is $4.53 \%$, and the removal rate increases by $48.22 \%$ and $-27.22 \%$. The corresponding temperatures are $22.40{ }^{\circ} \mathrm{C}$ and $19.50{ }^{\circ} \mathrm{C}$ respectively; the average $\mathrm{TN}$ removal rate is $61.62 \%$, and the maximum values of $95.37 \%$ and the minimum values of $23.16 \%$ correspond temperatures are $9.54{ }^{\circ} \mathrm{C}$ and $16.2^{\circ} \mathrm{C}$, respectively. According to the $\mathrm{TN}$ removal rate, the better temperature is $9.54{ }^{\circ} \mathrm{C}$, and the removal rate can reach $95.37 \%$, which is better than $80 \%$ (Wang et al., 2011). However, the dissolved oxygen value is as high as $3.70 \mathrm{mg} / \mathrm{L}$, which is much higher than $1.20 \pm 0.2 \mathrm{mg} / \mathrm{L}$ (Liu et al., 2011). Other temperatures are difficult to reach the Grade 1 B standard (GB18918-2002). Overall, the removal rate of TN has two critical points of $10.60{ }^{\circ} \mathrm{C}$ and $16.20^{\circ} \mathrm{C}$, and it is possible that $10.60{ }^{\circ} \mathrm{C}$ and $16.20^{\circ} \mathrm{C}$ are the extreme temperatures of certain low temperature denitrifying microorganisms and these require additional attention in future research.

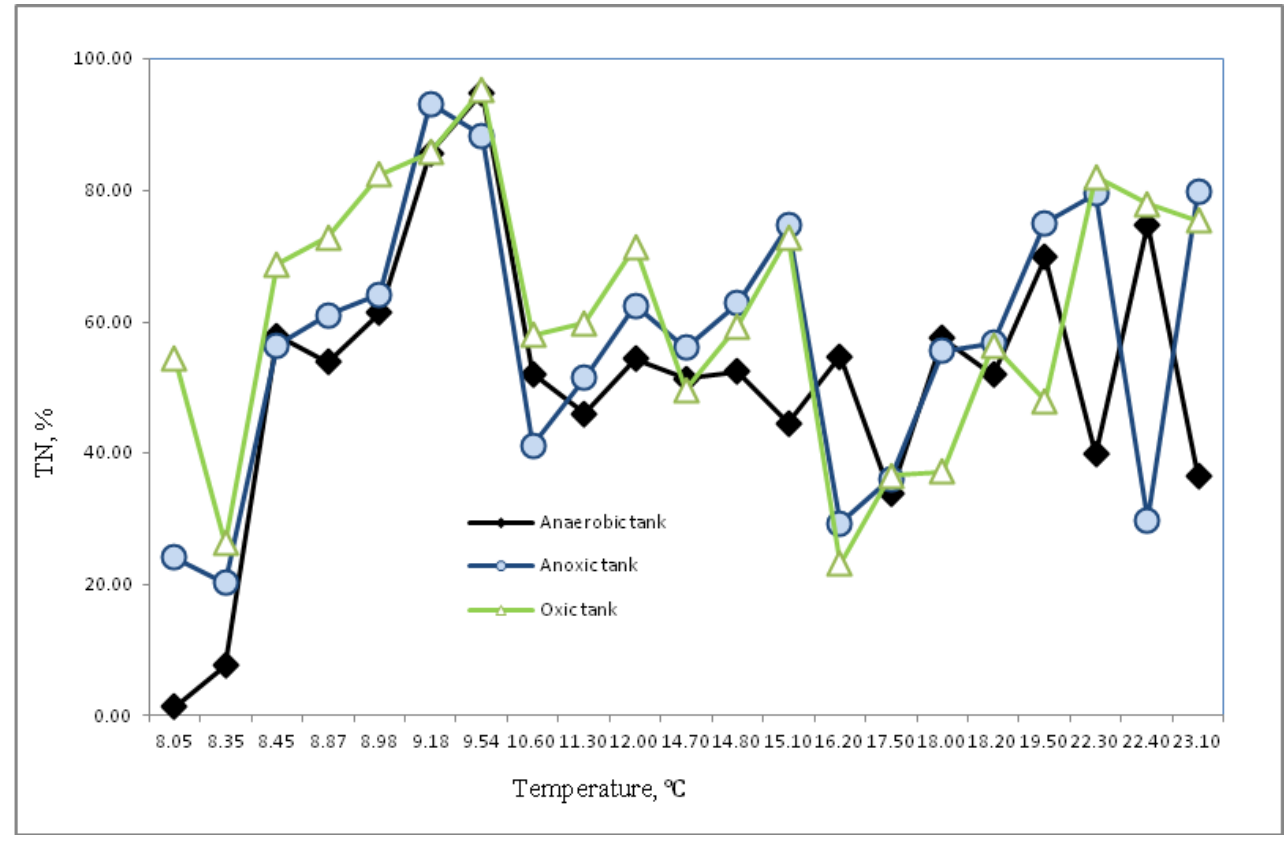

Figure 4. Removal rates of total nitrogen at different temperatures

As shown in Figure 5, the removal rate of $\mathrm{NH}_{4}{ }^{+}-\mathrm{N}$ in the anaerobic tank changes obviously between $9.36 \%$ and $97.23 \%$ under the fluctuation of temperature between $8{ }^{\circ} \mathrm{C}$ and $25{ }^{\circ} \mathrm{C}$, the removal rate of $\mathrm{NH}_{4}{ }^{+}-\mathrm{N}$ changes obviously. The average removal rate is $61.46 \%$, which is lower than $67.0 \%$ (Sohsalam and Sirianuntapiboon, 2008); the highest $\mathrm{NH}_{4}{ }^{+}-\mathrm{N}$ removal rate of $95.87 \%$ and the lowest value of $6.16 \%$ correspond temperatures are $22.30{ }^{\circ} \mathrm{C}$ and $8.35^{\circ} \mathrm{C}$, respectively. The anoxic tank contributes very little to the $\mathrm{NH}_{4}{ }^{+}-\mathrm{N}$ removal rate which is only increased by $4.04 \%$, which is lower than 
$16.12 \%$ (Sahariah et al., 2015), which increases the maximum value by $85.65 \%$ and the minimum value of $-1.38 \%$ corresponding to the temperatures of $9.18{ }^{\circ} \mathrm{C}$ and $8.05{ }^{\circ} \mathrm{C}$, respectively; the maximum removal rate of $95.08 \%$ and the minimum value of $9.36 \%$ corresponding temperatures are $95.02{ }^{\circ} \mathrm{C}$ and $8.05^{\circ} \mathrm{C}$. The $\mathrm{NH}_{4}{ }^{+}-\mathrm{N}$ in the oxic tank is not obvious due to the poor removal rate of anaerobic tank and anoxic tank, but the average value of the relative anoxic removal rate is $11.29 \%$, which is larger than $11 \%$ (Peng et al., 2005), the removal rate increases the maximum value $57.14 \%$ and the minimum value of $-2.50 \%$, the corresponding temperatures were $8.05{ }^{\circ} \mathrm{C}$ and $17.50{ }^{\circ} \mathrm{C}$, respectively; the average removal rate of $\mathrm{NH}_{4}{ }^{+}-\mathrm{N}$ was $77.42 \%$, and the maximum value of $98.12 \%$ and the minimum value of $34.83 \%$ corresponding temperatures are $22.30{ }^{\circ} \mathrm{C}$ and $8.35{ }^{\circ} \mathrm{C}$, respectively. According to the removal rate of $\mathrm{NH}_{4}{ }^{+}-\mathrm{N}$, the better temperature is $22.30{ }^{\circ} \mathrm{C}$, the removal rate can reach $98.12 \%$, and the measured $\mathrm{NH}_{4}{ }^{+}-\mathrm{N}$ effluent in the sedimentation tank can reach the first grade A standards (GB189182002), and the initial concentration is low so other temperatures can also reach this standard. In general, the two critical temperatures of $10.60{ }^{\circ} \mathrm{C}$ and $17.50{ }^{\circ} \mathrm{C}$ divide the curve into three parts. $8.05 \sim 9.54^{\circ} \mathrm{C}$ is the first part, which is a significant increase in the $\mathrm{NH}_{4}{ }^{+}-\mathrm{N}$ removal rate. $10.60 \sim 17.50{ }^{\circ} \mathrm{C}$ is the second part, which is not obvious for the $\mathrm{NH}_{4}{ }^{+}-\mathrm{N}$ removal rate. $17.50 \sim 23.10^{\circ} \mathrm{C}$ is the third part, which is a significant change in the TP removal rate. And it is possible that $10.60^{\circ} \mathrm{C}$ and $17.50{ }^{\circ} \mathrm{C}$ are the extreme temperatures of certain low temperature denitrifying microorganisms.

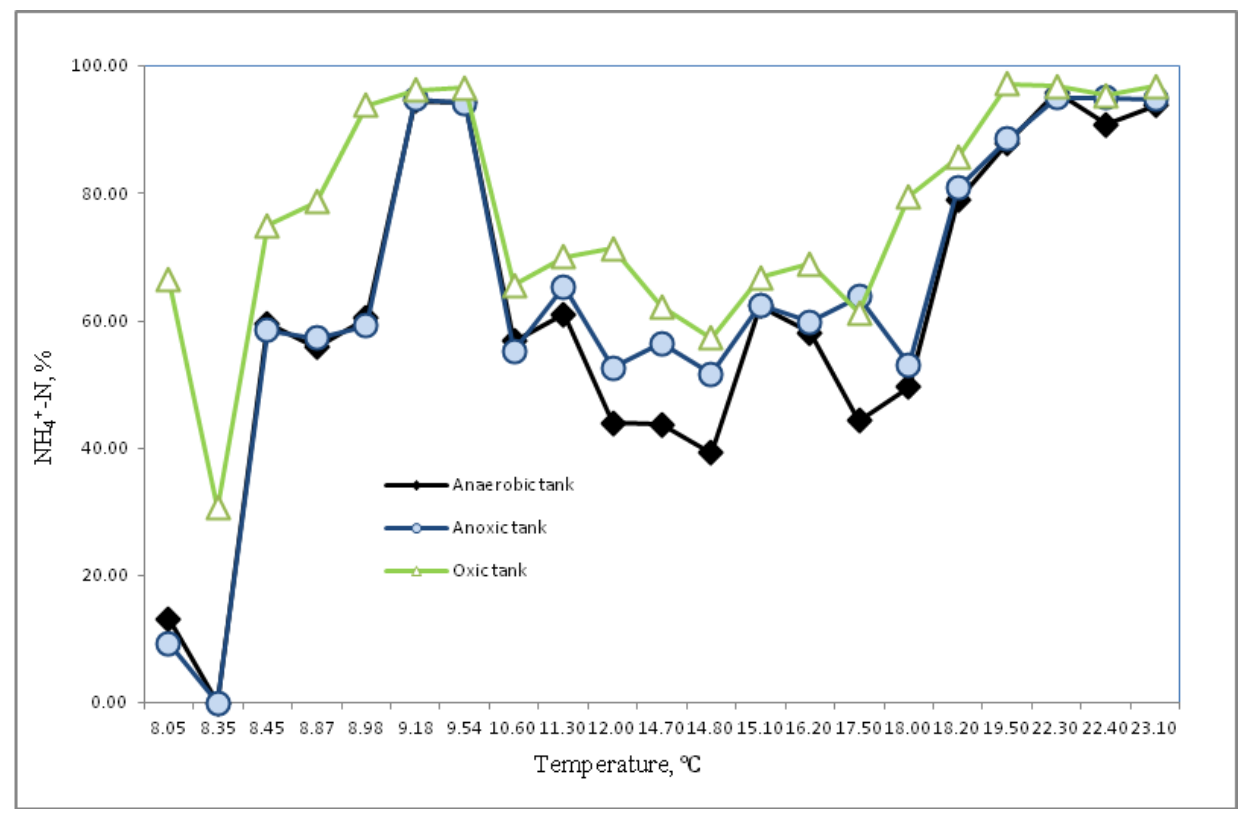

Figure 5. Removal rates of ammoniacal nitrogen at different temperatures

\section{Microorganisms}

The response of microorganisms in anaerobic tank, anoxic tank and oxic tank under temperature fluctuation of $8-25^{\circ} \mathrm{C}$ is shown in Figure 6.

It can be seen from Figure $6 a$ that the microbial density of anaerobic tanks generally shows a process of gradually decreasing from the high level and then increasing. The microbial density of the anoxic tank and oxic tank is flatter. The experiment showed that the microbial density in each tank was from $8{ }^{\circ} \mathrm{C}$ to $12{ }^{\circ} \mathrm{C}$ and $12{ }^{\circ} \mathrm{C}$ to $23.1{ }^{\circ} \mathrm{C}$. 
The microbial density of $8 \sim 12{ }^{\circ} \mathrm{C}$ showed a downward trend, which may be related to the higher temperature of sludge culture and domestication. The trend appeared in density; the microbial density of each tank showed a oscillating upward trend at $12{ }^{\circ} \mathrm{C}$ to $23.1^{\circ} \mathrm{C}$. Overall, the microbial density of anaerobic tanks was higher than that of anoxic tank and oxic tank. There was no significant difference in microbial density between anoxic tank and oxic tank, but the experimental microbial density was lower than $10^{8} \mathrm{CFU} / \mathrm{L}$ (Yang, 2017).

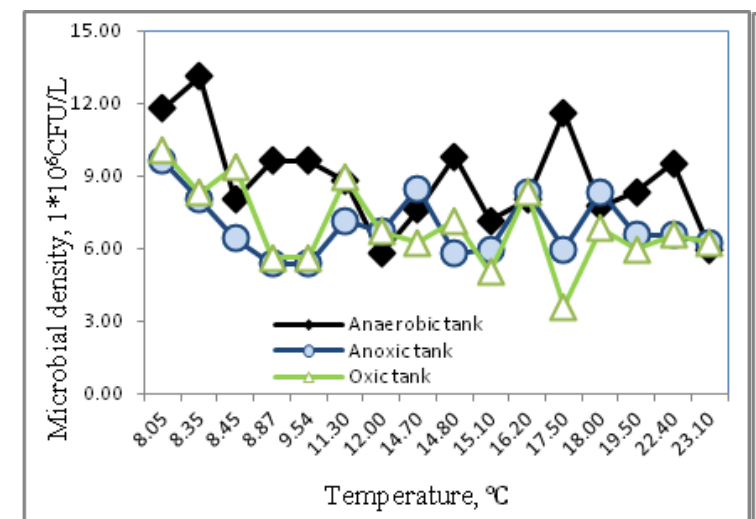

a

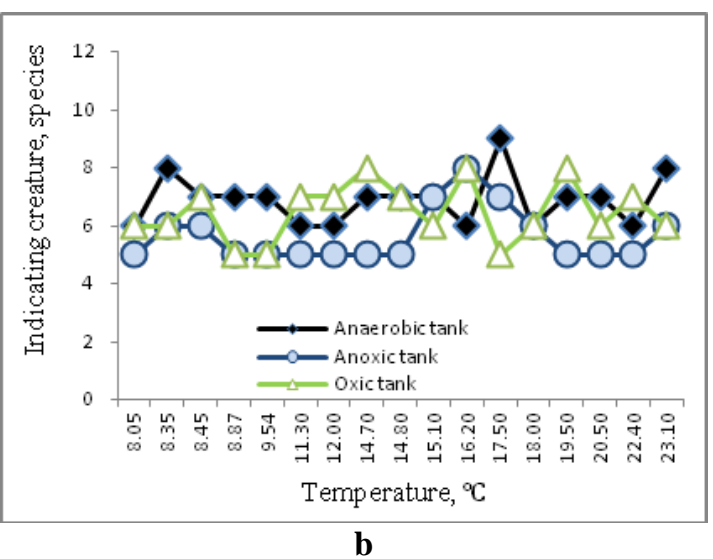

b

Figure 6. Microbial response at different temperatures

It can be seen from Figure $6 b$ that the relative changes of indicating creature are not significant in the three reaction cells, and the anaerbic tank and oxic tank indicate that the indicating creature are significantly better than the anoxic tank. Microscopic observations showed that the indicated microorganisms in each tank were pointed caterpillars, bell worms and trichinella, and the number of pointed caterpillars and bell worms decreased gradually while the trichinella showed an increasing trend. It has also been observed that Surticae has an increasing trend, which may be related to DO, and DO is greater than the minimum limit of $2.5 \mathrm{mg} / \mathrm{L}$ (Bernot and Wilson, 2012).

\section{Mixed liquid suspended solids and volume percent after settling for 30 min}

It can be seen from Figure 7 that MLSS shows a certain increasing trend with increasing temperature in the range of $8.05{ }^{\circ} \mathrm{C}$ to $11.3{ }^{\circ} \mathrm{C}$. In the range of $11.3{ }^{\circ} \mathrm{C}$ to $23.1^{\circ} \mathrm{C}$, MLSS shows a certain downward trend with increasing temperature; MLSS is less than 3,000 mg/L (Whang and Lim, 2008). SV30 shows a slow downward trend with increasing temperature.

\section{Discussion}

The removal contributions of anaerobic tank, anoxic tank, oxic tank and secondary sedimentation tank at the average removal rate of $\mathrm{COD}, \mathrm{TN}, \mathrm{NH}_{4}{ }^{+}-\mathrm{N}$ and $\mathrm{TP}$ are shown in Figure 8.

In addition to TP, the removal of $\mathrm{COD}, \mathrm{TN}$, and $\mathrm{NH}_{4}{ }^{+}-\mathrm{N}$ mainly occurs in anaerobic tank, while TP mainly occurs in anaerobic tank and oxic tank. The COD removal effect in each tank is consistent with the microbial density in the corresponding tank; the TP removal effect in each tank is consistent with the change trend of MLSS, and the two 
also exhibit a certain positive correlation, which is related to MLSS was key factors, which had a significant impact on Anaerobic phosphorus release and anoxic phosphorus uptake in the biological phosphorous removal process. Wang et al. (2007) are more consistent; TN and $\mathrm{NH}_{4}{ }^{+}-\mathrm{N}$ removal effects have a more consistent trend.

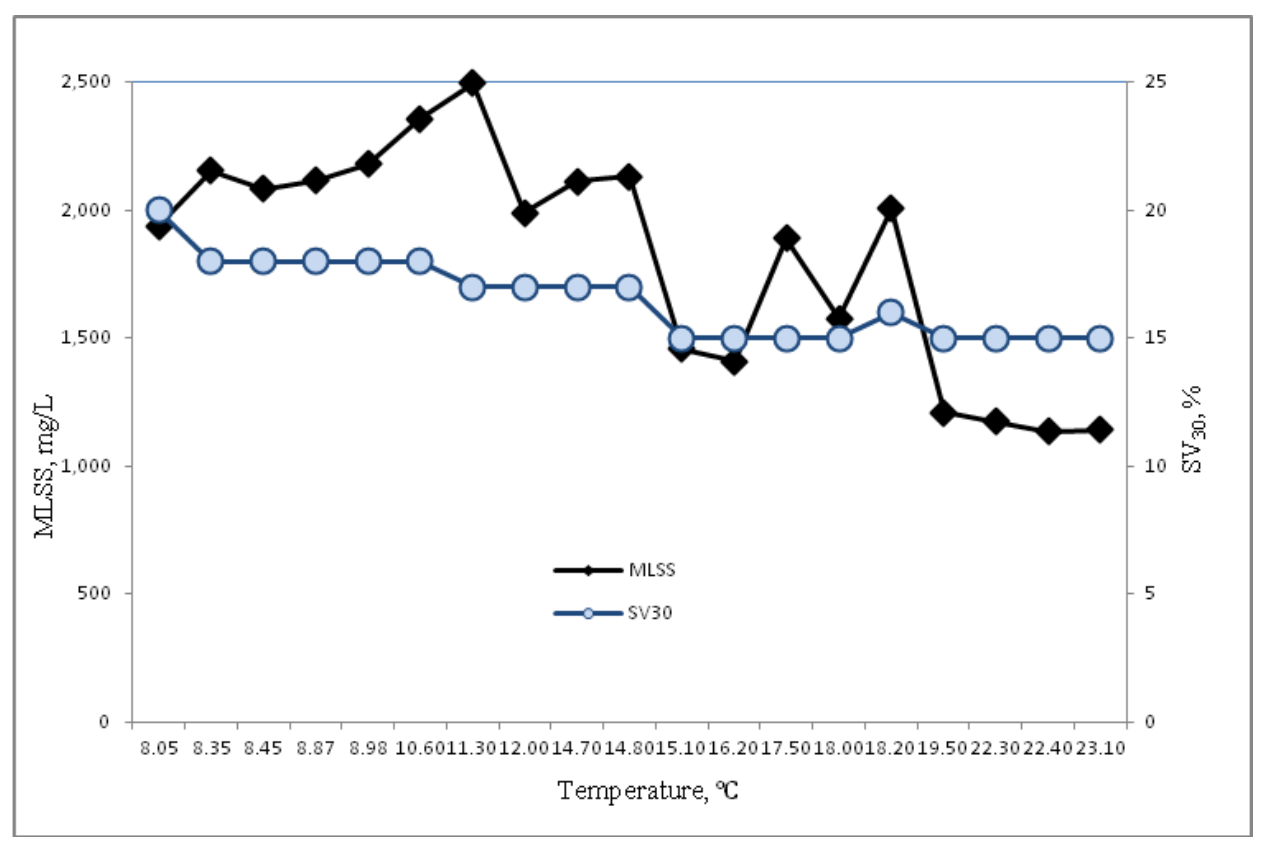

Figure 7. Mixed liquor suspended solids and volume percent after settling for 30 min at different hydraulic retention times

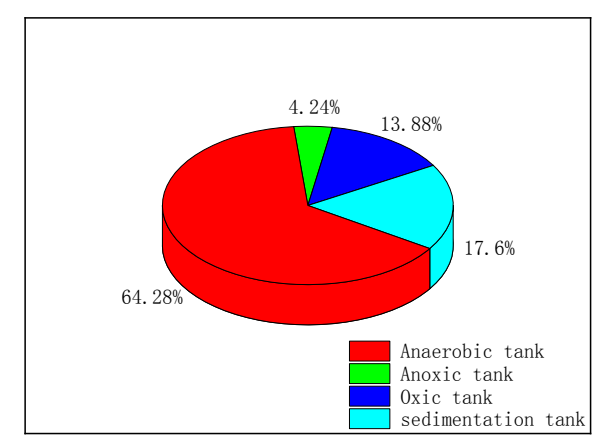

a

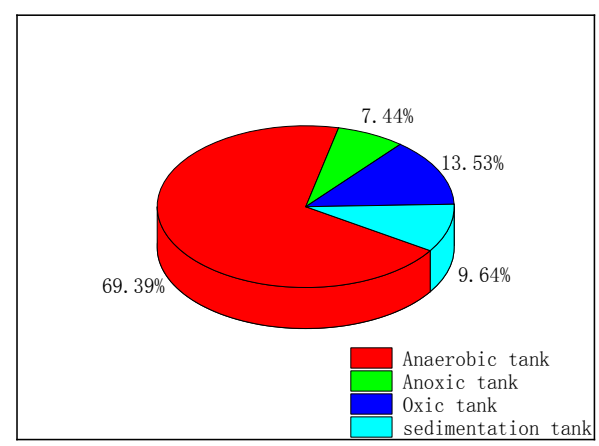

a

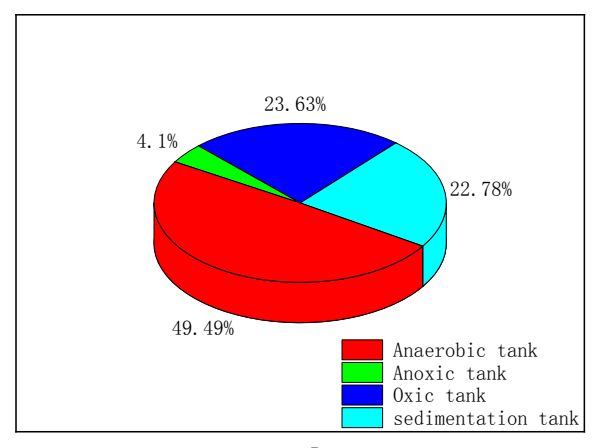

b

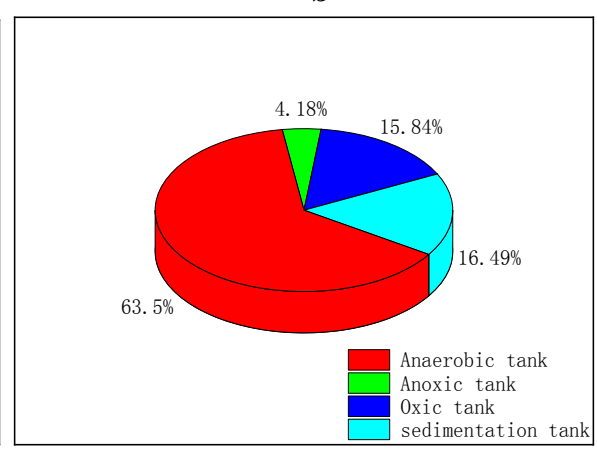

b

Figure 8. Removal contribution ratios of a chemical oxygen demand, $\boldsymbol{b}$ total phosphorous, $\boldsymbol{c}$ total nitrogen and $\boldsymbol{d}$ ammoniacal nitrogen of each tank 


\section{Conclusion}

Under the unique plateau environmental factors, the effects of temperature transients on COD, TP, TN, $\mathrm{NH}_{4}{ }^{+}-\mathrm{N}$ removal rate and microbial response were studied using a pilot-scale A2O process. The transient temperature changes show that the optimal removal rate of each water quality index is different. The COD removal rate maintains a good removal efficiency and the removal rate of TN, TP and $\mathrm{NH}_{4}{ }^{+}-\mathrm{N}$ in the anaerobic tank changes obviously under the temperature from $8{ }^{\circ} \mathrm{C}$ to $25^{\circ} \mathrm{C}$. The removal of COD, TN and $\mathrm{NH}_{4}{ }^{+}-\mathrm{N}$ mainly occurs in anaerobic tanks while TP mainly occurs in anaerobic and oxic tanks, anaerobic There is no obvious response relationship between microorganisms and indicator organisms in the tank, anoxic tank and oxic tank. The COD, TP, TN, $\mathrm{NH}_{4}{ }^{+}-\mathrm{N}$ in the effluent do not meet the Grade A standard, and the MLSS follows the increased temperature. The increase has not shown a significant growth trend. There are two distinct critical temperatures of $10.60{ }^{\circ} \mathrm{C}$ and $16.20^{\circ} \mathrm{C}$ to the $\mathrm{NH}_{4}{ }^{+}-$ $\mathrm{N}$ removal rate, of $10.60{ }^{\circ} \mathrm{C}$ and $17.50^{\circ} \mathrm{C}$ to the $\mathrm{TN}$ removal rate and of $9.54{ }^{\circ} \mathrm{C}$ and $14.70^{\circ} \mathrm{C}$ to the TP removal rate, and it is possible that two distinct critical temperatures are the extreme temperatures of certain low temperature denitrifying microorganisms. The above problems may be related to the long-term response time of temperature transient changes under high altitude environmental factors, and the corresponding mechanism needs to be studied later.

Acknowledgements. This work was supported by the National Natural Science Foundation of China (NO.51868069, 51769034) , Natural Science Foundation of Tibet (NO.XZ 2018 ZR G-20), the Program for Scientific Research Innovation Team in Colleges and Universities of Tibet Autonomous Region, Snowy Plateaus of Tibet Agriculture and Animal Husbandry College (Study on the operation status of typical sewage treatment plants in Tibet in China).

\section{REFERENCES}

[1] Ai, S. S., Zhang, X. H., Xiao, Y. B. (2014): Study on characteristics of activated sludge at low temperature. - Applied Mechanics \& Materials 675-677: 574-577.

[2] An, J., Xue, M., Xiang, C., et al. (2002): Isolation of psychrotrophs and their application to treatment of sewage in cold area. - Journal of Harbin Institute of Technology 34(4): $563-565+569$.

[3] Bao, K., Q., Gao, J. Q., Wang, Z. B. (2012): Enhanced removal of chemical oxygen demand, nitrogen and phosphorus using the ameliorative anoxic/anaerobic/oxic process and micro-electrolysis. - Water Science \& Technology 66(4): 850-857.

[4] Bernot, M. J., Wilson, K. P. (2012): Spatial and temporal variation of dissolved oxygen and ecosystem energetics in Devils Hole, Nevada. - Western North American Naturalist 72(3): 265-275.

[5] Chen, H., Wang, D., Li, X. (2014): Effect of dissolved oxygen on biological phosphorus removal induced by aerobic/extended-idle regime. - Biochemical Engineering Journal 90(9): 27-35.

[6] Chen, X. Y., Hao, K. Y., Su, D. (2018): Characteristic study on wastewater treatment in high altitude area by A2/O process. - Technology of water treatment 38(6): 93-96.

[7] He, J. G., Ke, L., Han, B. P. (2010): Study on the operational characteristics of hybrid A2/O process at low temperature. - Applied Mechanics \& Materials 39: 326-331.

[8] Huang, X., Dong, W., Wang, H. (2017): Biological nutrient removal and molecular biological characteristics in an anaerobic- multistage anaerobic/oxic (A-MAO) process to treat municipal wastewater. - Bioresource Technology 24: 969-978. 
[9] Li, S. M., Du, G. S., Tang, F. B. (2013): Nitrogen and phosphorus removal of modified A2/O process on low-carbon domestic sewage under low temperature. - Advanced Materials Research 777: 187-191.

[10] Li, S. M., Tong, H., Wang, R. B. (2014): Operation of modified A2/O process at low temperature and different sludge loadings. - China Water \& Wastewater 13: 64-68.

[11] Li, T., Bo, L., Yang, F. (2012): Comparison of the removal of COD by a hybrid bioreactor at low and room temperature and the associated microbial characteristics. Bioresource Technology 108(3): 28-34.

[12] Li, Y. F., Yang, J. Y., Zhang, G. C. (2013): Effects of aeration on nitrogen and phosphate removal with A2O process. - Advanced Materials Research 622-623: 1738-1741.

[13] Limpiyakorn, T., Shinohara, Y., Kurisu, F. (2005): Communities of ammonia-oxidizing bacteria in activated sludge of various sewage treatment plants in Tokyo. - Fems Microbiology Ecology 54(2): 205-217.

[14] Liu, G., Xu, X., Zhu, L. (2011): Biological nutrient removal in a continuous anaerobicaerobic-anoxic process treating synthetic domestic wastewater. - Chemical Engineering Journal 225: 223-229.

[15] Peng, Y. Z., Wang, X. L., Li, B. K. (2005): Anoxic biological phosphorus uptake and the effect of excessive aeration on biological phosphorus removal in the A2O process. Desalination 189(1): 155-164.

[16] Ruiz-Urbieta, M., Sparrow, E. M., Parikh, P. D. (1975): Two-film reflection polarizers: theory and application. - Applied Optics 14(2): 486-492.

[17] Sahariah, B. P., Anandkumar, J., Chakraborty, S. (2015): Treatment of coke oven wastewater in an anaerobic-anoxic-aerobic moving bed bioreactor system. Desalination \& Water Treatment 57(31): 1-7.

[18] Shen, N., Chen, Y., Zhou, Y. (2017): Multi-cycle operation of enhanced biological phosphorus removal (EBPR) with different carbon sources under high temperature. Water Research 114: 308-315.

[19] Sohsalam, P., Sirianuntapiboon, S. (2008): Feasibility of using constructed wetland treatment for molasses wastewater treatment. - Bioresource Technology 99(13): 56105616.

[20] Wang, Y. Y., Pan, M. L., Yan, M. (2007): Characteristics of anoxic phosphors removal in sequence batch reactor. - Journal of Environmental Sciences 19(7): 776-782.

[21] Wang, Y. Y., Geng, J. J., Guo, G. (2011): N2O production in anaerobic/anoxic denitrifying phosphorus removal process: the effects of carbon sources shock. - Chemical Engineering Journal 172(2-3): 9 99-1007.

[22] Whang, G. D., Lim, D. M. (2008): A study on the treatment efficiency of A2O process coupled with mesh screening reactor. - Journal of Korean Society of Water and Wastewater 22(6): 705-714.

[23] Xing, J., Yu, C., Wang, W. (2013): Effect of partial oxygen pressures on pollutant removal with membrane-aerated bioreactor. - Advanced Materials Research 773: 347352.

[24] Yang, T. (2017): Study on Degradation Regularity of Three Characteristic Pollutants of Pharmaceutical Park Tail Water in A2O Treatment Process. - Liaoning University, Shenyang.

[25] Yoo, H. S., Lee, B. (2015): A study on adjustment of operational factor in A2O process. Korea Organic Resource Recycling Association 23(3): 33-41.

[26] Zhang, L. H., Zhuang, Y. P., Wang, X. M. (2016): Effect of temperature on denitrifying phosphorus removal efficiency using modified A2/O process. - Transactions of the Chinese Society of Agricultural Engineering 32(10): 213-219.

[27] Zhou, J., Gao, J., Liu, Y. (2013): Contaminant removal performances on domestic sewage using modified anoxic/anaerobic/oxic process and micro-electrolysis. - Environmental Technology 34(19): 2773-2779. 
[28] Zong, Y. C. (2017): Preliminary influence study of Tibet natural environment on sewage treatment effect. - Municipal Technology 35(3): 132-136.

[29] Zong, Y. C., Zhang, Y. H., Lu, G. H. (2018): Study on process characteristics of high altitude A2/O process based on principal component analysis. - Technology of Water Treatment 38(9): 116-119. 